\title{
EARNINGS MANAGEMENT IN RUSSIAN COMPANIES: PROFESSIONAL ETHICS OF OPERATING DECISIONS
}

\author{
Y.S. LEEVIK \\ National Research University Higher School of Economics at St.Petersburg, \\ Russia
}

The problem of earnings management is on of most topical issues in accounting practice worldwide. There are many reasons for this phenomenon. In this paper we will follow papers [Fischer, Rosenzweig, 1995; Geiger et al., 2006] to present the results of analysis of a survey of Russian respondents concerning their attitudes on the ethical acceptability of earnings management. It occurs that Russian respondents' behavior is different from other countries and we find factors that are associated with these differences. On the other hand, it was found that Russia is not significantly different in earnings management perception from market oriented developed countries.

Keywords: earnings management, ethics, financial reporting, accounting, accruals.

JEL: M41.

\section{Introduction}

Earnings are the profits of a company. Investors and analysts look at earnings to determine the attractiveness of a company. Companies with poor earnings prospects will typically have lower share prices than those with good prospects. A company's capability to generate profit in the future plays a very important role in determining a share's price.
Earnings management represents a strategy used by the management of a company to deliberately manipulate the company's earnings so that the figures match a pre-determined target. The purpose of this practice is income smoothing. Thereby, rather than having years of very good or extremely bad earnings, companies will try to keep the performance results relatively stable by adding and removing cash from reserve accounts.

E-mail: yuleevik@hse.ru

Postal Address: 3 Kantemirovskaya ul., National Research University Higher School of Economics at Saint Petersburg, St.Petersburg, 194100, Russia.

(C) Y.S. Leevik, 2017

https://doi.org/10.21638/11701/spbu18.2017.409 
Although the different methods used by managers to smooth earnings can be very complex and confusing, the important thing is that the driving force behind earnings management is to meet a pre-specified target. As the great investor Warren Buffett once said: "Managers that always promise to "make the numbers" will at some point be tempted to make up the numbers".

According to [Healy, Wahlen, 1999], "earnings management" occurs when managers use judgment in financial reporting and in structuring transactions to alter financial reports to either mislead some stakeholders about the underlying economic performance of a company or influence contractual outcomes that depend on reported accounting numbers.

Management wishing to show earnings at a certain level or following a certain pattern seek loopholes in financial reporting standards that allow them to adjust the numbers as far as is practicable to achieve their desired aim or to satisfy projections by financial analysts. These adjustments amount to fraudulent financial reporting when they fall "outside the bounds of acceptable accounting practice". Drivers for such behavior include market expectations, personal realization of a bonus, and maintenance of position within a market sector. In most cases conformance to acceptable accounting practices is a matter of personal integrity.

There is a variety of forms of earnings management. It includes the practices of selectively choosing accounting estimates and timing operating or investment decisions to move reported earnings toward a desired goal (see [Schipper, 1989; Merchant, Rockness, 1994; Healy, Wahlen, 1999]). Examples of earnings management also include delaying the recognition of expenses to avoid violating debt covenants.

Other motives for earnings management include maximizing bonus compensation [Healy, 1985], meeting analysts' earnings forecasts [Burgstahler, Eames, 1998], and trying to achieve protection from foreign competitors [Jones, 1991].
A large body of empirical evidence suggests that companies adopt several forms of earnings management [Burgstahler, Dichev, 1997; Burgstahler, Eames, 1998; Healy, Wahlen, 1999; Brown, 2001]. For deeper analysis of earnings management see also [Cahan, 1992; DeFond, Jiambalvo, 1994; Perry, Williams, 1994; Erickson, Wang, 1999]. At the same time [Fischer, Rosenzweig, 1995] found that the direction of manipulation (increasing earnings or decreasing earnings) is very important for respondents when studing ethical acceptability of earnings management.

Let us start our examples of earnings management from recent cases in the United States America. Bank of America Corp. and Citigroup Inc. incorrectly hid from investors billions of dollars of their debt, similar to what Lehman Brothers Holdings Inc. did to obscure its level of risk, company documents show. In recent filings with regulators, the two big banks disclosed that over the past three years 2007-2010, they at times erroneously classified some short-term repurchase agreements, or "repos", as sales when they should have been classified as borrowings. Though the transactions involved billions of dollars, they represented relatively small amounts for the banks. A bankruptcy-court examiner had been doing the same thing to make its balance sheet look better before it filed for bankruptcy in September 2008, using a strategy dubbed "Repo 105" that helped the Wall Street firm move $\$ 50$ billion in assets off its balance sheet. Bank of America and Citigroup say that their misclassifications were due to errors - not an attempt to make themselves look less risky, which was Lehman's motivation. The disclosures, made after federal securities regulators began asking financial firms about their repo accounting, were included in quarterly filings earlier this month but not highlighted. The disclosures come amid a series of revelations about how banks obscure their risk-taking before reporting their finances to the public, a practice known in the financial world as "window dressing". Bank of America and Citigroup were among the banks cited in a page-one 
Wall Street Journal article detailing how financial firms temporarily shed repo debt at the ends of quarters, when they report their finances to investors. Since the financial crisis began, both banks often have reduced their quarter-end repo debt from their average borrowings for the same quarter. That activity did not involve misclassifying repo loans as sales. Repos are short-term loans that allow banks to take higher risks on securities trades. Classifying the transactions as sales instead of borrowings allows a firm to take assets off its balance sheet and thus reduces its reported leverage, or assets as a multiple of equity capital. Federal securities rules bar financial firms from intentionally masking debt to deceive investors. There is no indication that Bank of America or Citigroup misclassified their repos intentionally or that the Securities and Exchange Commission will take any action against them. The misclassifications had tiny impacts on the banks' reported leverage, and none at all on their earnings or shareholder equity. The banks did not restate any financial statements. Bank of America said the misclassified transactions in certain quarters over the past three years-ranging from $\$ 573$ million to as much as $\$ 10,7$ billion "represented substantially less than $1 \%$ of our total assets" and had no material impact on its balance sheet, earnings or borrowing ratios. Citigroup said the misclassified transactions of $\$ 5,7$ billion as of the end of 2009 , and as much as $\$ 9,2$ billion over the past three years involved "a very limited number of our business units" that "used this type of transaction in very small amounts". It also said its errors were immaterial to its financial statements. The SEC had asked big banks in March 2010 for more information about their repo accounting in the wake of the Lehman bankruptcy report. Bank of America and Citigroup indicated they had found their errors on their own initiative. More broadly, the SEC is now considering stricter disclosure and a clearer rationale from firms about quarter-end borrowing activities.

In [Armstrong, 1993] author claims that earnings management is one of the most im- portant ethical financial reporting. The role of accountants in providing the investors with reliable financial information (in the form of financial statements) for decisionmaking is very high. Differing national perceptions were described in [Meirovich, Reichel, 2000]. They showed that Russian executives believe it is not possible to operate in a completely legal manner given the existing conditions in the country. As a result, these managers have employed very creative manipulation techniques described as "perpetually being improved". Moreover, it was stated in [Meirovich, Reichel, 2000] that these illustrated perceptions are an outgrowth of the nation's culture and history. So, the authors suggest that national culture has a significant impact on the perceived acceptability of earnings management. This study also investigates whether the acceptability of earnings management in Russia vary across different national cultures.

\section{Purpose of the study and hypotheses}

Earnings management can be carried out in different ways. Modern national and international accounting standards give managers a certain freedom in choosing accounting policy. In [Merchant, Rockness, 1994; Fischer, Rosenzweig, 1995] authors suggested two forms of earnings management, accounting methods and operating methods. Their study showed that companies perceive the practice of operating manipulations more favorable than accounting manipulations. Accounting methods allow achieving the following. First, to redistribute the financial result of the organization between the reporting periods, in other words, the total amount of income and expenses for the operation remains constant, and only the time of their recognition changes. For example, R\&D costs are divided into research costs and development costs. In most national accounting systems research costs are recognized as expenses of the period at the time of their occurrence and development costs are capitalized when certain conditions are met. 
However, if the organization, in particular, cannot distinguish the stages of research and development, then all costs are considered research costs. It follows that the organization can either relate all expenses for the current period, or capitalize part of the costs related to the development stage, thereby increasing the current financial result.

Secondly, the choice of these or other methods and instruments allows to redistribute income and expenses between operational and others. Thus, it is possible to improve the financial result from the main activity. For example, by choosing how to write off interest on loans for other operating expenses you can increase the gross profit compared to using the method of capitalization of borrowing costs. Operating methods involve the real implementation of so-called "necessary" operations. The need to accomplish the operation is not caused by the economic need but solely with a goal to manage financial reports. The traditional tool of this method is the sale of an asset with income followed by its return purchase or lease.

This research was motivated by several considerations. First, in spite of the effects of internal corporate governance in developing countries, Russian corporate governance mechanisms may be less effective due to several factors, such as insufficient independence of directors and ownership concentration. Second, Russia has similar factors to other developing countries such as low investor rights, inactive regulations and opacity of higher-level earnings management. Finally, previous studies have investigated earnings management practices in different legal environments and economies; however, the Russian environment has not yet been the subject of academic studies, which would play a significant role in improving perception of earnings management.

Thus, the main purpose of this study was to assess the attitudes on the ethical acceptability of earnings management of Russian respondents and to compare these results with the other countries based on the research data of [Geiger et al., 2006]. Since this study follows a deductive methodology, primary hypotheses was formulated similarly to the above-mentioned studies.

H1. Russian companies perceive the practice of operating manipulations more favorable than accounting manipulations. H2. Russian companies perceive more favorable manipulations with income rather than with expenses.

\section{Methodology}

This study was undertaken in two phases: (1) a questionnaire survey and (2) data analysis.

Data were collected through the use of a questionnaire. The respondents in the study were asked to evaluate the ethical acceptability of 13 earnings management activities taken by a hypothetical profit center manager by indicating their judgment using the following scale:

1) ethical practice;

2) questionable practice. I would not say anything to the manager, but it makes me uncomfortable;

3) minor infraction. The manager should be warned not to do it again;

4) serious infraction. The manager should be severely reprimanded;

5) totally unethical. The manager should be fired.

The thirteen earnings management questions borrowed from [Geiger et al., 2006] are listed in the Appendix. The research uses the general logic of [Bruns, Merchant, 1990; Merchant, Rockness, 1994; Fischer, Rosenzweig, 1995] to analyze the perception of respondents regarding the practices of earnings management. Like the [Merchant, Rockness, 1994] the 5-point scale ranging from 1 for "ethical practice" to 5 for "totally unethical practice" is used. The higher scores in the scale indicate that individuals perceived the proposed action as less ethical.

The original 13 earnings management questions can be grouped by the following forms and factors (table 1). Earnings can be manipulated in two broad ways. First, man- 
Types of earnings management questions

\begin{tabular}{|c|c|c|}
\hline Forms of earnings management & Factor & Question \\
\hline \multirow[t]{7}{*}{ Accounting method } & \multirow[t]{3}{*}{ Inventory manipulation } & 5b. Write-down inventory \\
\hline & & 6a. Write-up inventory - product development \\
\hline & & 6b. Write-up inventory - meet budget \\
\hline & \multirow[t]{4}{*}{ Accrual manipulation } & 3. Record supplies next year \\
\hline & & 5a. Prepay travel expenses \\
\hline & & 7a. Delay recording invoice $-\$ 30000$ \\
\hline & & 7b. Delay recording invoice $-\$ 500000$ \\
\hline \multirow[t]{6}{*}{ Operating method } & \multirow[t]{3}{*}{ Operating expenses } & 1. Paint building early \\
\hline & & 2a. Defer expenditures for quarter \\
\hline & & 2b. Defer expenditures for year \\
\hline & \multirow[t]{3}{*}{ Operating revenue } & 4a. End of year sales program \\
\hline & & 4b. Overtime in December \\
\hline & & 4c. Sell unused assets \\
\hline
\end{tabular}

agers could alter the recording of existing transactions (this way refers to accounting method). Second, managers could resort to timing operating activities near year-end to move revenues and expenses into desired periods (it refers to operating method). The example of an operating method in the used questionnaire is the question 2 (manager orders his employees to defer discretionary expenditures until the next accounting period). Question 6 in which the manager manipulates his division's inventory reserve is an example of an accounting method.

To analyze differences in means between the constructed groups of earnings management questions the simple $t$-test was used.

\section{Respondents}

The study includes a sample of Russian industrial and retail companies with location in Central part of Russia, Ural and Siberia over a period of five years between 2007 and 2012. In total 150 questionnaires were distributed, of which 13 were not fully completed and therefore were not taken into account when processing the results. Among 137 respondents in this study there were $51 \%$ of women and $49 \%$ of men. Participation was voluntary and anonymous. For the purposes of the comparative analysis, the total number of companies for this study was chosen by analogy with the sample sizes of previous studies [Merchant, Rockness, 1994; Fischer, Rosenzweig, 1995; Geiger et al., 2006].

The sample was formed according to two criteria: (1) the annual revenue is not less than 1 billion rubles; (2) number of employees is not less than 1 thousand employees. The sample of Russian industrial and retail companies represents nine industries: power engineering, metal industry, machine building, trade, construction, chemical industry, oil and gas industry, transport, pulp and paper industry.

The three groups of respondents are listed in the table 2 .

In our sample 129 (94\%) respondents have high professional education, 5 (4\%) respondents have a science degree and only 3 respondents $(2 \%)$ have only secondary education. Overall median age for all respondents is 40 years.

\section{Results}

Table 3 shows the mean scores and standard deviations for the responses of the entire set of 137 Russian respondents for each of the 13 questions grouped by factors on which they loaded highly. 
Table 2

Classification of respondents

\begin{tabular}{l|c|c|c}
\hline \multicolumn{1}{c|}{ Group } & Job experience, years & Number of respondents & Share, \% \\
\hline General managers, business owner's & 5,5 & 64 & 47 \\
\hline Operating-unit controllers & 4,6 & 51 & 37 \\
\hline Corporate staff & 3,9 & 22 & 16 \\
\hline In total & & 137 & 100 \\
\hline
\end{tabular}

Table 3

Mean scores of earnings management variables, grouped by factors

\begin{tabular}{|c|c|c|c|c|c|c|}
\hline $\begin{array}{c}\text { Forms } \\
\text { of earnings } \\
\text { management }\end{array}$ & Factor & Question & Mean & $\begin{array}{l}\text { Std } \\
\text { dev. }\end{array}$ & $\begin{array}{c}\text { Mean of } \\
\text { factor }\end{array}$ & $\begin{array}{l}\text { Std dev. } \\
\text { of factor }\end{array}$ \\
\hline \multirow{7}{*}{$\begin{array}{l}\text { Accounting } \\
\text { method }\end{array}$} & \multirow{3}{*}{$\begin{array}{l}\text { Inventory } \\
\text { manipula- } \\
\text { tion }\end{array}$} & 5b. Write-down inventory & 3,27 & 1,18 & \multirow[t]{3}{*}{2,91} & \multirow[t]{3}{*}{1,23} \\
\hline & & 6a. Write-up inventory - product development & 2,79 & 1,23 & & \\
\hline & & 6b. Write-up inventory - meet budget & 2,68 & 1,28 & & \\
\hline & \multirow{4}{*}{$\begin{array}{l}\text { Accrual } \\
\text { manipula- } \\
\text { tion }\end{array}$} & 3. Record supplies next year & 2,95 & 1,09 & \multirow[t]{4}{*}{2,58} & \multirow[t]{4}{*}{1,20} \\
\hline & & 5a. Prepay travel expenses & 2,60 & 1,30 & & \\
\hline & & 7a. Delay recording invoice $-\$ 30000$ & 1,99 & 1,03 & & \\
\hline & & 7b. Delay recording invoice $-\$ 500000$ & 2,79 & 1,37 & & \\
\hline \multirow{6}{*}{$\begin{array}{l}\text { Operating } \\
\text { method }\end{array}$} & \multirow{3}{*}{$\begin{array}{l}\text { Operating } \\
\text { revenue }\end{array}$} & 4a. End of year sales program & 2,63 & 1,26 & \multirow[t]{3}{*}{2,21} & \multirow[t]{3}{*}{1,14} \\
\hline & & 4b. Overtime in December & 2,01 & 1,16 & & \\
\hline & & 4c. Sell unused assets & 2,00 & 1,01 & & \\
\hline & \multirow{3}{*}{$\begin{array}{l}\text { Operating } \\
\text { expenses }\end{array}$} & 1. Paint building early & 1,95 & 1,21 & \multirow[t]{3}{*}{2,11} & \multirow[t]{3}{*}{1,15} \\
\hline & & 2a. Defer expenditures for quarter & 1,72 & 1.07 & & \\
\hline & & 2b. Defer expenditures for year & 2,65 & 1.16 & & \\
\hline
\end{tabular}

The first two lines of table 4 compare the mean scores for the questions describing accounting methods of managing earnings with those describing operating methods. It shows a difference; the accounting methods were judged much more strictly than operating methods. The last two lines of table 4 show that the actions which increased earnings were not rated significantly different from those which decreased earnings.

Thus hypothesis H1 is supported. The results obtained correspond with findings by [Bruns, Merchant, 1990; Fischer, Rosenzweig, 1995] and confirm that three surveyed groups (general managers \& business owners; operating-unit controllers; corporate staff) show a greater tolerance for operating manipulation than for accounting manipulation. In Russia managers often think of ethics as a list of rules. The widespread logic is that if something is not directly prohibited then ethics rules are not violated.

Hypothesis H2 is not supported. Direction of manipulation (increasing earnings or decreasing earnings) is not important for Russian respondents. In this part there is a slight difference from the results obtained by Fisher \& Rosenzweig. In their study respondents perceive more favorable manipulations with income rather than with expenses.

Table 5 indicates the mean scores to each of the 13 earnings management questions by country including Russia. For comparative analysis we used the data of [Geiger et al., 2006].

Table 5 shows that the 5 earnings management questions $(1,2 \mathrm{a}, 2 \mathrm{~b}, 7 \mathrm{a}, 7 \mathrm{~b})$ were 
valued by Russian respondents as less ethically troubling than by respondents from other eight countries.

Table 6 in its turn obviously demonstrates that Russia is the most tolerant country to accounting methods of earning management. However from the table 7 we can see that as to operational methods Russia is not separated from other eight countries considered.

\section{Conclusion}

Financial reporting is an instrument of dialogue of management of the companies with an external world. In some cases the management has an aspiration to reflect in the published financial reports the results which are distinct from realities of an economic situation in the company. According to statistical data in the USA for 2003 as a result of swindle in the financial reporting the cumulative damage, put to its users, has made $\$ 660$ billion [Alexander, Britton, Jorissen, 2005]. At today's market the value of the company is determined basically in a trading hall of a stock exchange. Investors, market analysts, and also shareholders - all of them are interested in the future company potential. One of the basic problems, with
Table 4

Mean scores of earnings management variables, grouped by two attributes

\begin{tabular}{|c|c|c|c|c|}
\hline Attribute & Question & $\begin{array}{l}\text { Mean } \\
\text { (Std } \\
\text { dev.) }\end{array}$ & $\begin{array}{l}t \text {-sta- } \\
\text { tistic }\end{array}$ & $\begin{array}{c}\text { H1/H2 } \\
\text { support }\end{array}$ \\
\hline $\begin{array}{l}\text { Account- } \\
\text { ing } \\
\text { method }\end{array}$ & $\begin{array}{l}3,5 \mathrm{a}, 5 \mathrm{~b}, \\
6 \mathrm{a}, 6 \mathrm{~b}, \\
7 \mathrm{a}, 7 \mathrm{~b}\end{array}$ & $\begin{array}{c}2,75 \\
(1,21)\end{array}$ & \multirow[t]{2}{*}{$\begin{array}{l}t=3,20 \\
p<0,01\end{array}$} & \multirow[t]{2}{*}{ Yes } \\
\hline $\begin{array}{l}\text { Operating } \\
\text { method }\end{array}$ & $\begin{array}{l}1,2 \mathrm{a}, 2 \mathrm{~b} \\
4 \mathrm{a}, 4 \sigma, 4 \mathrm{c}\end{array}$ & $\begin{array}{c}2,16 \\
(1,14)\end{array}$ & & \\
\hline $\begin{array}{l}\text { Increases } \\
\text { earnings }\end{array}$ & $\begin{array}{l}2 \mathrm{a}, 2 \mathrm{~b}, 3, \\
4 \mathrm{a}, 4 \mathrm{~b}, \\
4 \mathrm{c}, 6 \mathrm{a}, \\
6 \mathrm{~b}, 7 \mathrm{a}, 7 \mathrm{~b}\end{array}$ & $\begin{array}{c}2,42 \\
(1,17)\end{array}$ & \multirow[t]{2}{*}{$t=0,97$} & \multirow[t]{2}{*}{ No } \\
\hline $\begin{array}{l}\text { Decreases } \\
\text { earnings }\end{array}$ & $1,5 \mathrm{a}, 5 \mathrm{~b}$ & $\begin{array}{c}2,60 \\
(1,23)\end{array}$ & & \\
\hline
\end{tabular}

which they now collide, is that the companies consider the annual report as certain type of "goods". There are special structural divisions in the companies involved in preparation of the annual reports and all of them aspire to letting out something glossier than their competitors.

This research has confirmed the hypotheses only partially. Therefore it is possible to draw a conclusion that the market system dynamically develops in Russia. Distinctions

Table 5

Average scores of earnings management questions: differences across countries

\begin{tabular}{c|c|c|c|c|c|c|c|c|c}
\hline Question & USA & Spain & Australia & Indonesia & Hong Kong & Malaysia & Singapore & United Kingdom & Russia \\
\hline 1 & 1,14 & 1,48 & 1,26 & 1,61 & 1,36 & 1,64 & 1,20 & 1,20 & 1,95 \\
\hline $2 \mathrm{a}$ & 2,88 & 2,80 & 2,69 & 2,82 & 2,51 & 2,95 & 3,05 & 2,75 & 1,72 \\
\hline $2 \mathrm{~b}$ & 3,49 & 3,39 & 3,06 & 3,18 & 3,00 & 3,27 & 3,50 & 3,16 & 2,65 \\
\hline 3 & 3,24 & 3,48 & 3,10 & 3,32 & 2,85 & 3,14 & 3,15 & 2,86 & 2,95 \\
\hline $4 \mathrm{a}$ & 2,05 & 2,17 & 1,89 & 2,96 & 2,08 & 2,00 & 2,65 & 1,88 & 2,63 \\
\hline $4 \mathrm{~b}$ & 1,74 & 2,25 & 1,78 & 2,21 & 1,95 & 1,86 & 1,75 & 1,94 & 2,01 \\
\hline $4 \mathrm{c}$ & 1,70 & 2,68 & 1,84 & 2,18 & 2,00 & 1,95 & 2,20 & 1,53 & 2,00 \\
\hline $5 \mathrm{a}$ & 2,66 & 2,79 & 2,71 & 2,86 & 2,85 & 2,77 & 3,25 & 2,41 & 2,60 \\
\hline $5 \mathrm{~b}$ & 3,24 & 3,30 & 3,07 & 2,64 & 2,92 & 2,82 & 3,25 & 3,17 & 3,27 \\
\hline $6 \mathrm{a}$ & 2,66 & 2,85 & 2,61 & 2,43 & 2,46 & 2,50 & 2,45 & 2,27 & 2,79 \\
\hline $6 \mathrm{~b}$ & 3,25 & 3,15 & 2,84 & 2,79 & 2,54 & 2,50 & 2,70 & 2,76 & 2,68 \\
\hline $7 \mathrm{a}$ & 2,86 & 2,97 & 2,54 & 2,75 & 2,87 & 2,68 & 2,65 & 2,57 & 1,99 \\
\hline $7 \mathrm{~b}$ & 3,83 & 3,93 & 3,42 & 3,79 & 3,44 & 3,41 & 3,80 & 3,39 & 2,79 \\
\hline
\end{tabular}


Table 6

Average scores for earnings management practices: differences across countries (accounting methods)

\begin{tabular}{l|c}
\hline \multicolumn{1}{c|}{ Country } & Score \\
\hline Spain & 3,21 \\
\hline USA & 3,10 \\
\hline Singapore & 3,04 \\
\hline Indonesia & 2,94 \\
\hline Australia & 2,90 \\
\hline Hong Kong & 2,85 \\
\hline Malaysia & 2,83 \\
\hline United Kingdom & 2,78 \\
\hline Russia & 2,75 \\
\hline
\end{tabular}

in ethics of acceptance of management decisions in comparison with other developed countries gradually disappear. Influence of cultural features of socialism epoch has noticeably weakened. Today it is impossible to approve that Russia is the country with a marginal level of a collectivism and a high distance of authority. New businessmen and managers are people having modern formation in the field of the management. They are ready
Table 7

Average scores for earnings management practices: differences across countries (operating methods)

\begin{tabular}{l|l}
\hline \multicolumn{1}{c|}{ Country } & Score \\
\hline Indonesia & 2,49 \\
\hline Spain & 2,46 \\
\hline Singapore & 2,39 \\
\hline Malaysia & 2,28 \\
\hline USA & 2,17 \\
\hline Russia & 2,16 \\
\hline Hong Kong & 2,15 \\
\hline Australia & 2,09 \\
\hline United Kingdom & 2,08 \\
\hline
\end{tabular}

to state professional judgement, to defend it and to bear for it the responsibility.

However for contemporary Russia there is still no exact statistics about unfair manipulations in the financial reporting and ways of their detection. Considering that in Russian companies the reporting under the international standards actively takes root it is necessary to expect very similar tendencies as in the world practice.

Appendix ${ }^{1}$

\section{Instructions}

The following questions reflect everyday ethical choices. Please evaluate the practices as they apply to a major division (annual revenues of, say, $\$ 100$ million) of a billion dollar public company. Use the following scale to indicate how you judge their acceptability:

1) ethical practice;

2) questionable practice. I would not say anything to the manager, but it makes me uncomfortable;

3) minor infraction. The manager should be warned not to do it again;

4) serious infraction. The manager should be severely reprimanded;

5) totally unethical. The manager should be fired.

\section{Questions}

1. The division's headquarters building was scheduled to be painted in 2008. But since profit performance was way ahead of budget in 2007, the division general manager (GM) decided to have the work done in 2007. Amount: $\$ 150000$.

2. The GM ordered his employees to defer all discretionary expenditures (e.g., travel, advertising, hiring, maintenance) into the next accounting period, so his division could make its budgeted profit targets. Expected amount of deferrals: \$150 000 .

(a) The expenses were postponed from February and March until April in order to make the first quarter target.

\footnotetext{
1 We follow [Geiger et al., 2006] for the sake of compatibility of the results.
} 
(b) The expenses were postponed from November to December until January in order to make the annual target.

3. On December 15 , a clerk ordered $\$ 3000$ of office supplies, and the supplies were delivered on December 29. This order was a mistake because the GM had ordered that no discretionary expenses be incurred for the remainder of the fiscal year, and the supplies were not urgently needed. The company's accounting policy manual states that office supplies are to be recorded as an expense when delivered. The GM learned what had happened, and to correct the mistake, he asked the accounting department not to record the invoice until February.

4. In September, the GM realized the division would need strong performance in the fourth quarter to reach its budget targets.

(a) He decided to implement a sales program offering liberal payment terms to pull some sales that would normally occur next year into the current year; customers accepting delivery in the fourth quarter would not have to pay the invoice for 120 days.

(b) He ordered manufacturing to work overtime in December so that everything possible could be shipped by the end of the year.

(c) He sold some excess assets and realized profit of $\$ 40000$.

5. At the beginning of December 2007, the GM realized that the division would exceed its budgeted profit targets for the year.

(a) He ordered his controller to prepay some expenses (e.g., hotel rooms, exhibit expense) for a major trade show to be held in March 2008 and to book them as 2007 expenses. Amount: $\$ 60000$.

(b) He ordered his controller to develop the rationale for increasing the reserve for inventory obsolescence. By taking a pessimistic view of future market prospects, the controller was able to identify $\$ 700000$ worth of finished goods that conservative accounting would say should be fully reserved (i.e., written off), even though the GM was fairly confident that the inventory would still be sold at a later date at close to full price.

6. The next year, the division sold $70 \%$ of the written-off inventory, and a customer had indicated some interest in buying the rest of that inventory the following year. The GM ordered his controller to prepare the rationale for reducing the reserve for obsolescence by $\$ 210000$ (i.e., writing up the previously written-off goods to full cost). The GM's motivation for recapturing the profit was: (a) delayed due to budget constraints;

(b) to make budgeted profit targets.

7. In November 2007, the division was straining to meet budget. The GM called the engagement partner of a consulting firm that was doing some work for the division and asked that the firm not send an invoice until next year. The partner agreed. Estimated work done but not invoiced:

(a) $\$ 30000$

(b) $\$ 500000$.

\section{REFERENCES}

Alexander D., Britton A., Jorissen A. 2005. International Financial Reporting and Analysis. 2nd ed. Thomson Learning.

Armstrong M.B. 1993. Ethics and Professionalism for CPAs. South-Western: Cincinnati, $\mathrm{OH}$.

Brown L. D. 2001. A temporal analysis of earnings surprises: Profits vs losses. Journal of Accounting Research 39 (2): 221-241.

Bruns W. J.Jr., Merchant K.A. 1990. The dangerous morality of managing earnings. Management Accounting 72 (2): 22-25.
Burgstahler D., Dichev I. 1997. Earnings management to avoid earnings decreases and losses. Journal of Accounting and Economics 24 (1): 99-126.

Burgstahler D., Eames M. 1998. Management of Earnings and Analyst Forecasts. Working Paper, University of Washington.

Cahan S.F. 1992. The effect of antitrust investigations on discretionary accruals: A refined test of the political-cost hypothesis. Accounting Review 67 (1): 77-95. 
DeFond M.L., Jiambalvo J. 1994. Debt covenant violation and manipulation of accruals. Journal of Accounting and Economics 17 (1-2): 145-176.

Erickson M., Wang S.-W. 1999. Earnings management by acquiring firms in stock for stock mergers. Journal of Accounting and Economics 27 (2): 149-176.

Fischer M., Rosenzweig K. 1995. Attitudes of students and accounting practitioners concerning the ethical acceptability of earnings management. Journal of Business Ethics 14 (6): 433-444.

Geiger M.A., O'Connell B.T., Clikeman P.M., Ochoa E., Witkowski K., Basioudis I. 2006. Perception of earnings management: The effects of national culture. Advances in International Accounting 19: 175-199.

Healy P.M. 1985. The effect of bonus schemes on accounting decisions. Journal of Accounting and Economics 7 (1-3): 85-107.
Healy P., Wahlen J.M. 1999. A review of the earnings management literature and its implications for standard setting. Accounting Horizons 13 (4): 365-383.

Jones J. 1991. Earnings management during import relief investigations. Journal of Accounting Research 29 (2): 193-228.

Meirovich G., Reichel A. 2000. Illegal but ethical: An inquiry into the roots of illegal corporate behaviour in Russia. Business Ethics 9 (3): 126-135.

Merchant K.A., Rockness J. 1994. The ethics of managing earnings: An empirical investigation. Journal of Accounting and Public Policy 13 (1): 79-94.

Perry S.E., Williams T.H. 1994. Earnings management preceding management buyout offers. Journal of Accounting and Economics 18 (1): 157-179.

Schipper K. 1989. Commentary on earnings management. Accounting Horizons 3 (4): 91-102.

Initial Submission: December 5, 2017 Final Version Accepted: December 22, 2017

\section{Управление прибылью в российских колпаниях: профессиональная этика операционных решений}

\section{Ю. С. Леевик}

Национальный исследовательский университет «Высшая школа эконолики» - Санкт-

Петербург, Россия

E-mail: yuleevik@hse.ru

Проблема управления прибылью одна из наиболее актуальных в практике бухгалтерского учета во всем мире. Этому есть множество объяснений. В данной статье мы следуем подходу работ [Fischer, Rosenzweig, 1995; Geiger et al., 2006] и представляем результаты опроса российских респондентов об их отношении к этической приемлемости управления прибылью. Поведение российских респондентов отличается от других стран, в которых проводился подобный опрос. В статье отмечены факторы, связанные с этими различиями. В то же время было обнаружено, что Россия не сильно отличается в восприятии управления прибылью от рыночно ориентированных стран с развитой экономикой.

Ключевые слова: управление прибылью, деловая этика, финансовая отчетность, бухгалтерский учет, начисления.

JEL: M41.

https://doi.org/10.21638/11701/spbu18.2017.409

Статья поступила в редакиию

5 декабря 2017 г.

Принята к публикации

22 декабря 2017 г. 